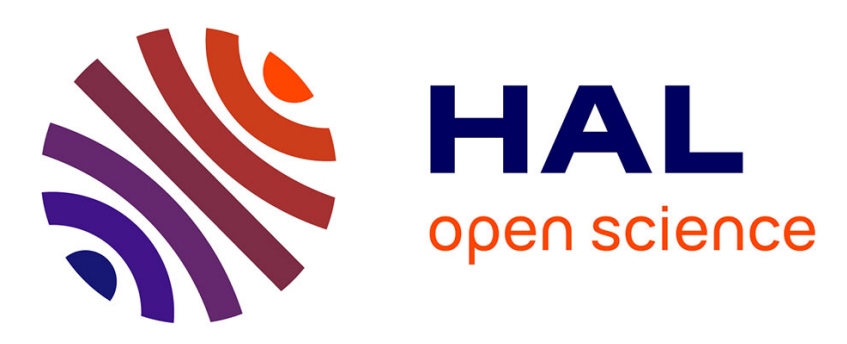

\title{
Effect of fibre- and starch-rich finishing diets on methanogenic Archaea diversity and activity in the rumen of feedlot bulls
}

Milka Popova, C. Martin, Maguy Eugène, Marie-Madeleine Mialon, M. Doreau, Diego Morgavi

\section{To cite this version:}

Milka Popova, C. Martin, Maguy Eugène, Marie-Madeleine Mialon, M. Doreau, et al.. Effect of fibre- and starch-rich finishing diets on methanogenic Archaea diversity and activity in the rumen of feedlot bulls. Animal Feed Science and Technology, 2011, 166-167, pp.113-121. 10.1016/j.anifeedsci.2011.04.060 . hal-02454712

\author{
HAL Id: hal-02454712 \\ https://hal.uca.fr/hal-02454712
}

Submitted on 29 May 2020

HAL is a multi-disciplinary open access archive for the deposit and dissemination of scientific research documents, whether they are published or not. The documents may come from teaching and research institutions in France or abroad, or from public or private research centers.
L'archive ouverte pluridisciplinaire HAL, est destinée au dépôt et à la diffusion de documents scientifiques de niveau recherche, publiés ou non, émanant des établissements d'enseignement et de recherche français ou étrangers, des laboratoires publics ou privés. 


\title{
Effect of fibre- and starch-rich finishing diets on methanogenic Archaea diversity and activity in the rumen of feedlot bulls
}

\author{
M. Popova, C. Martin, M. Eugène, M.M. Mialon, M. Doreau, D.P. Morgavi* \\ INRA, UR1213 Herbivores, F-63122 Saint-Genès-Champanelle, France
}

\section{A R T I C L E I N F O}

\section{Keywords:}

Methanogens

Methane

Bulls

mcrA

qPCR

DGGE

\begin{abstract}
A B S T R A C T
Methanogenesis plays an important role in maintaining low hydrogen partial pressure in the rumen and consequently in feed digestion. Diet composition and lipid supplementation are known to influence the extent of methane $\left(\mathrm{CH}_{4}\right)$ production in ruminants. However, the impact of diet composition on rumen methanogens is poorly understood. This study examined $\mathrm{CH}_{4}$ production and methanogen community abundance, diversity and metabolic activity in the rumen of fattening bulls fed a fibrous diet $(F ; n=10)$ or a starch rich diet

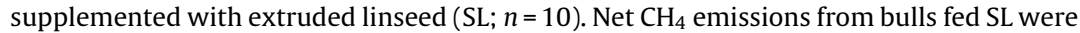
lower than emissions from bulls fed F. Methanogenic Archaea were studied using culture independent methods targeting the functional mcrA gene. Methanogen abundance was similar in the two groups of bulls, but protozoa numbers were $65 \%$ lower in the F group. The SL diet decreased methanogen diversity and metabolic activity, which were evaluated by PCR-DGGE and reverse transcriptase qPCR, respectively. In contrast, no changes occurred in bacterial numbers and diversity between diets. Data indicate that reduction in net $\mathrm{CH}_{4}$ production with the SL diet was associated with changes in rumen microbiota, particularly methanogen activity. Characterization of the activity and structure of the whole rumen microbiota should provide a better prediction of methanogenesis.

This paper is part of the special issue entitled: Greenhouse Gases in Animal Agriculture Finding a Balance between Food and Emissions, Guest Edited by T.A. McAllister, Section Guest Editors; K.A. Beauchemin, X. Hao, S. McGinn and Editor for Animal Feed Science and Technology, P.H. Robinson.
\end{abstract}

(C) 2011 Elsevier B.V. All rights reserved.

\section{Introduction}

Methane $\left(\mathrm{CH}_{4}\right)$ is produced in the gastrointestinal tract of ruminants by a particular group of microbes, the methanogenic Archaea (Baldwin and Allison, 1983). Methanogens use dihydrogen $\left(\mathrm{H}_{2}\right)$ to reduce carbon dioxide to $\mathrm{CH}_{4}$, thus keeping $\mathrm{H}_{2}$ partial pressure low and favouring fermentation of feeds. However, $\mathrm{CH}_{4}$ is an undesirable end product of rumen fermentation as it represents an energy loss to the host animal and because it is a greenhouse gas.

Various strategies have been proposed to reduce enteric $\mathrm{CH}_{4}$ emissions, mainly by dietary manipulation (Martin et al., 2010). $\mathrm{CH}_{4}$ production/ $\mathrm{kg}$ product in feedlot cattle decreases with increasing proportion of starch in the diet (Beauchemin and McGinn, 2005; Doreau et al., 2011). Lipid supplementation, within levels that do not affect dietary digestion and animal

\footnotetext{
Abbreviations: cDNA, complementary DNA; DGGE, denaturing gradient gel electrophoresis; DM, dry matter; qPCR, real time quantitative polymerase chain reaction; $\mathrm{SF}_{6}$, sulfur hexafluoride; $\mathrm{tNA}$, total nucleic acids.

* Corresponding author. Tel.: +334736240 57; fax: +33473624659

E-mail address: diego.morgavi@clermont.inra.fr (D.P. Morgavi).
} 
Table 1

Chemical composition of the experimental diets.

\begin{tabular}{|c|c|c|c|}
\hline & \multicolumn{2}{|l|}{ Diet $^{\mathrm{a}}$} & \multirow[t]{2}{*}{ Barley straw } \\
\hline & $\mathrm{F}$ & SL & \\
\hline Organic matter (g/kg DM $\left.{ }^{\mathrm{b}}\right)$ & 800 & 824 & 852 \\
\hline Crude protein (g/kg DM) & 159 & 200 & 41 \\
\hline aNeutral detergent fibre ( $\mathrm{g} / \mathrm{kg} \mathrm{DM})$ & 379 & 196 & 601 \\
\hline aAcid detergent fibre (g/kg DM) & 206 & 104 & 383 \\
\hline Starch (g/kg DM) & 75 & 337 & 31 \\
\hline Ether extract (g/kg DM) & 28 & 47 & - \\
\hline Gross energy (MJ/kg DM) & 18.9 & 19.7 & 19.3 \\
\hline
\end{tabular}

a Diet rich in fibre (F) or rich in starch and supplemented with lipids (SL).

b DM, Dry matter.

performance, has also been shown to generally decrease $\mathrm{CH}_{4}$ production (Beauchemin et al., 2008; Eugène et al., 2008; Martin et al., 2008, 2010). It was recently shown that the combined effect of a high starch diet supplemented with extruded linseed reduced $\mathrm{CH}_{4}$ production in feedlot bulls compared to a diet higher in fibre (Eugène et al., in this issue).

Previous findings suggest that there is no link between $\mathrm{CH}_{4}$ production in ruminants and the numbers of methanogens in faunated and defaunated sheep (Newbold et al., 1995; Popova et al., 2010a) or with a coconut oil supplemented diet (Machmüller et al., 2003). In contrast, there was a shift in methanogen diversity in the rumen of steers following a switch from a low to high concentrate diet (Zhou et al., 2010), but $\mathrm{CH}_{4}$ production was not measured. The methanogenic communities in ruminants with high and low residual feed intake fed a low energy diet were also reported to differ (Zhou et al., 2009). Understanding the ecology of methanogens in ruminants fed different diets can help to elucidate the microbial mechanisms of $\mathrm{CH}_{4}$ production in the rumen.

The methanogenic pathway involves a series of co-enzymes, many of them unique and ubiquitous to methanogens (Rouviere and Wolfe, 1988). For instance, methyl coenzyme-M reductase is crucial to the terminal step of methanogenesis and the $m c r A$ gene coding for this enzyme can be used as a phylogenetic and functional marker to enumerate methanogens and to assess their diversity in an ecosystem (Luton et al., 2002). Targeting a gene which codes for an enzyme also offers the potential for development of activity based detection methods by analysis of messenger RNA. Thus molecular biology tools that target the mcrA gene in DNA and mRNA extracted from the rumen are a reliable method to estimate the abundance, diversity and activity of rumen methanogens.

The aim of our work was to compare the methanogenic community in terms of number, diversity and metabolic activity in the rumen of young bulls fed two feedlot diets differing in the amount of fibre and energy dense starch and lipid components.

\section{Materials and methods}

\subsection{Animals, diet and experimental design}

The study was conducted at the animal experimental facilities of INRA's Experimental Unit in Bourges (France) and at the Herbivore Research Unit in Saint-Genès Champanelle (France). Animal procedures were in accordance with the guidelines for animal research of the French Ministry of Agriculture and applicable European guidelines and regulations for animal experimentation (www2.vet-lyon.fr/ens/expa/acc_regl.html).

Animals and treatments are described in Eugène et al. (in this issue). Briefly, bulls were divided in two groups and fed two fattening diets for 16-18 mo until slaughter. The two dietary treatments consisted of a diet rich in fibre (F) and a diet rich in starch supplemented with lipids (SL). Both diets were composed of concentrate and of barley straw offered ad libitum. Concentrate of the F diet (on a dry matter (DM) basis) consisted mainly of cereal by-products (403 g/kg, wheat and maize bran), dehydrated lucerne pellets (224), dehydrated beet pulp (212), rapeseed and palm kernel meal (75) and other ingredients (86). The concentrate of the SL diet consisted mainly of cereals (464; barley, maize and oat grains), dehydrated beet pulp (60), rapeseed meal (214) and a linseed mixture (120) containing extruded linseed and other components to achieve a theoretical level of $12 \mathrm{~g} / \mathrm{kg}$ of DM as omega-3 fatty acids from linseed. Ingredients such as molasses and soya meal (142) completed the diet. Eugène et al. (in this issue) includes details of the analysis methods and the full list of ingredients. The complete chemical composition of the diets is in Table 1. Feed intake was recorded $5 \mathrm{~d} /$ wk and bulls were weighed every 2 wk. From the total of 50 bulls used by Eugène et al. (in this issue), 10 bulls were randomly selected from each diet group for our study.

\section{2. $\mathrm{CH}_{4}$ production}

$\mathrm{CH}_{4}$ production was measured at the start, middle and end of the fattening period. Each bull was measured individually during a $5 \mathrm{~d}$ period using the sulfur hexafluoride $\left(\mathrm{SF}_{6}\right)$ tracer technique (Eugène et al., in this issue). Only results of $\mathrm{CH}_{4}$ production at the end of fattening from the 20 bulls were used in the data presented here. 


\subsection{Rumen content sampling for fermentation and microbial parameters}

Bulls were slaughtered at INRA-Theix's experimental abattoir at average age of $18 \pm 1.3$ mo and body weight of $711 \pm 55.8 \mathrm{~kg}$. The entire gastrointestinal tract was removed as soon as possible after slaughter and representative samples of homogenised rumen contents were collected and weighed along with whole rumen contents.

The $\mathrm{pH}$ was measured with a portable $\mathrm{pH}$-meter (CG840, electrode $\mathrm{Ag} / \mathrm{AgCl}$, Schott Geräte, Hofheim, Germany) at 5 locations immediately after opening the rumen. An aliquot of rumen contents $(\sim 250 \mathrm{~g})$ was strained through polyester monofilament fabric ( $250 \mu \mathrm{m}$ mesh aperture) to separate the liquid phase. For volatile fatty acids (VFA), $0.8 \mathrm{ml}$ rumen fluid filtrate was mixed with $0.5 \mathrm{ml}$ of $4 \mathrm{mg} / \mathrm{ml}(\mathrm{w} / \mathrm{v}$ ) crotonic acid and $20 \mathrm{mg} / \mathrm{ml}$ (w/v) metaphosphoric acid in $0.5 \mathrm{M} \mathrm{HCl}$, kept at $4{ }^{\circ} \mathrm{C}$ for at least $2 \mathrm{~h}$, centrifuged $\left(16,500 \times \mathrm{g}\right.$ for $10 \mathrm{~min}$ at $\left.4{ }^{\circ} \mathrm{C}\right)$ and supernatant stored at $-20^{\circ} \mathrm{C}$ until analysis. VFA were analysed by gas chromatography using crotonic acid as the internal standard (Morgavi et al., 2003) on a CP 9002 Gas Chromatography (Chrompack, Middelburg, Germany). One ml of rumen fluid was added to $1 \mathrm{ml} \mathrm{MFS}$ solution (35 ml/1 formaldehyde, $0.14 \mathrm{M} \mathrm{NaCl}, 0.92 \mathrm{mM}$ methylgreen) and stored in the dark at room temperature (i.e., $21^{\circ} \mathrm{C}$ ) until protozoa were counted. Rumen fluid/MFS solutions were diluted in an equal volume of Phosphate Buffer Saline (PBS) before protozoa enumeration (Ranilla et al., 2007) under a microscope $(\times 400)$ in a Neubaeur Chamber.

Another aliquot of total rumen contents $(\sim 30 \mathrm{~g})$ was diluted with $15 \mathrm{ml}$ ice cold PBS pH 6.8 and homogenised, for three 1 min cycles with 1 min intervals on ice, using a Polytron grinding mill (Kinematica GmbH, Steinhofhalde Switzerland). Approximately $0.5 \mathrm{~g}$ were transferred to a $2 \mathrm{ml}$ Eppendorf tube and mixed with $1 \mathrm{ml}$ of RNALater ${ }^{\circledR}$ Tissue Collection:RNA Stabilization Solution (Applied Biosystems, Austin, TX, USA). Tubes were kept at $4{ }^{\circ} \mathrm{C}$ overnight to allow the solution to thoroughly penetrate the cells, as suggested by the manufacturer, and stored at $-80^{\circ} \mathrm{C}$ until molecular analyses.

\subsection{Total nucleic acids extraction and cDNA synthesis}

Total nucleic acids (tNA) were extracted as described by Popova et al.(2010b). Each tNA sample was divided into two equal fractions; DNA in one of the fractions was digested with rDNase, RNase-free (from the Total RNA Isolation Kit, Machenery Nagel, France) using a modified protocol, as described by Popova et al. (2010b).

The yield and purity of extracted tNA and RNA samples were assessed by optical density measurements using a NanoQuant Plate on an Infinity spectrophotometer (TECAN, Switzerland). RNA integrity was estimated with the Agilent RNA 6000 Nano Kit on an Agilent 2100 bioanalyzer (Agilent Technologies, Santa Clara, CA, USA) according to the manufacturer's recommendations. Results were analysed using the Software 2100 Expert, version B.02.07.SI482 (Beta; Agilent Technologies, Waldbronn, Germany). Indicators of RNA integrity were the RNA Integrity Number (RIN, maximum value 10), the 23S rRNA/16S rRNA ratio (optimum value 2) and the absence of degradation (low baseline; Schroeder et al., 2006).

Total RNA $(1 \mu \mathrm{g})$ was reverse transcribed in cDNA using Random Primers (Promega, Madison, WI, USA) $0.5 \mu \mathrm{g} / \mu \mathrm{g}$ RNA. To allow template/primers to anneal, the mixture was brought to $70{ }^{\circ} \mathrm{C}$ for $5 \mathrm{~min}$ followed by $5 \mathrm{~min}$ on ice. After annealing, a buffer mixture containing AMV reverse transcriptase (Promega, Madison, WI, USA), dNTP and DEPC-treated water was added to each tube and reverse transcription was performed for $60 \mathrm{~min}$ at $37^{\circ} \mathrm{C}$ using MyCycler thermal Cycler (BioRad, Hercules, CA, USA). In a final volume of $40 \mu \mathrm{l}$, each reaction had $0.625 \mathrm{mM}$ each dNTP, 30 units of AMV reverse transcriptase and $1.25 \times$ reaction buffer supplied with the enzyme.

A negative control with no template was completed for the reaction mixture. In addition, a negative control without addition of reverse transcriptase was completed for each sample. These negative controls were also used in subsequent PCR and qPCR reactions to confirm the amplification of cDNA templates free of DNA contamination.

\subsection{Microbial diversity analysis by PCR-DGGE}

The mcrA and rrs genes were used as molecular markers for methanogen and bacterial populations, respectively. For PCR amplification, $50 \mathrm{ng}$ of total nucleic acids samples and $5 \mu \mathrm{l}$ of cDNA samples were used.

PCR amplification of the mcrA sequences used the primers previously described to be specific for methanogens (Table 2) with the addition of a GC clamp (40 bp) at the 5'-end of the forward primer (Muyzer et al., 1993). Each reaction contained in

Table 2

Oligonucleotides used for PCR-DGGE and qPCR analysis.

\begin{tabular}{|c|c|c|c|c|c|}
\hline Oligonucleotides & Oligonucleotide Sequences & Target & Amplicon length (bp) & Use in & References \\
\hline $534 \mathrm{R}-341 \mathrm{f}-\mathrm{GC}$ & $\begin{array}{l}\text { 5'-ATT ACC GCG GCT GCT GG } \\
5^{\prime}-(\mathrm{GC})-C C \text { TAC GGG AGG CAG CAG }\end{array}$ & rrs Bacteria & 193 & PCR-DGGE & Muyzer et al. (1993) \\
\hline mcrAr - mcrAf-GC & $\begin{array}{l}\text { 5'-TTC ATT GCR TAG TTW GGR TAG TT } \\
\text { 5'-(GC)-GGT GGT GTM GGA TTC ACA } \\
\text { CAR TAY GCW ACA GC }\end{array}$ & mcrA Methanogens & $460-490$ & PCR-DGGE & Luton et al. (2002) \\
\hline qmcrA-R - qmcrA-F & $\begin{array}{l}\text { 5'-GBARGTCGWAWCCGTAGAATCC } \\
\text { 5'-TTCGGTGGATCDCARAGRGC }\end{array}$ & mcrA Methanogens & 140 & qPCR & Denman et al. (2007) \\
\hline 799R2 - 520F & $\begin{array}{l}\text { 5'-AACAGGATTAGATACCCTG } \\
\text { 5'-AGCAGCCGCGGTAAT }\end{array}$ & rrs Bacteria & 280 & qPCR & Edwards et al. (2007) \\
\hline
\end{tabular}


a $50 \mu \mathrm{l}$ final volume, 1.25 units of HotStarTaq DNA Polymerase (Qiagen), $1 \times$ PCR Buffer (supplied with the enzyme), $3 \mathrm{mM}$ $\mathrm{MgCl}_{2}, 0.2 \mathrm{mM}$ dNTP mix (Sigma, St. Louis, MO, USA) and $0.25 \mu \mathrm{M}$ each primer. PCR was performed using MyCycler thermal Cycler (BioRad Laboratories) according to the protocol of Luton et al. (2002).

The V3 region of the bacterial rrs gene was amplified in PCR using primers 341f-GC clamp and 534r (Table 2). Each reaction contained in $50 \mu \mathrm{l}$ final volume 1.25 units of HotStarTaq DNA Polymerase (Qiagen), $1 \times$ PCR Buffer (supplied with the enzyme), $0.2 \mathrm{mM}$ dNTP mix and $0.25 \mu \mathrm{M}$ of each primer. PCR was performed using MyCycler thermal Cycler (BioRad Laboratories) as described by Sadet et al. (2007).

PCR amplification products were analysed by agarose gel $(20 \mathrm{mg} / \mathrm{ml}$ of TAE Buffer $1 \times, 40 \mathrm{mM}$ Tris base, $40 \mathrm{mM}$ glacial acetic acid, $1 \mathrm{mM}$ EDTA) electrophoresis using ethidium bromide staining. Amplicon size and concentration were estimated using a Low DNA Mass Ladder (Invitrogen Corporation, Carlsbad, CA, USA) and an imaging system ChemImager (Alpha Innotech, San Leandro, CA, USA).

PCR products were loaded onto a $6-8 \mathrm{mg} / \mathrm{ml}(\mathrm{w} / \mathrm{v})$ gradient polyacrylamide gel with different ranges of denaturant concentrations ( $100 \%$ denaturant was defined as $7 \mathrm{~mol} / \mathrm{l}$ urea and $400(\mathrm{v} / \mathrm{v})$ formamide (Muyzer et al., 1993)). The $\mathrm{mcrA}$ PCR products were applied to a gradient of $10-30 \%$ denaturant. The denaturant gradient used to separate the bacterial rrs PCR products was 30-55\%. DGGE was run in 0.5 $\times$ TAE Buffer for $5.3 \mathrm{~h}$ (for $\mathrm{mcr} A$ ) and $5 \mathrm{~h}$ (for $r r s$ ) at $60^{\circ} \mathrm{C}$ using a fixed voltage of $200 \mathrm{mV}$ in DGGE 2001 (CBS Scientific Co, Del Mar, CA, USA). Approximately $100 \mathrm{ng}$ of PCR product for both $m c r A$ and $r r s$ were loaded per well of the polyacrylamide gel.

Gels were silver stained using a commercial kit (BioRad Laboratories). The large number of samples required several gels to complete the study. To normalize for differences among gels, an outside sample from a wether was used as the standard. The same $m c r A$ or $r r s$ PCR products of this rumen sample were run on every gel and used as standard for comparison of gels. The similarity of standards between gels was $90.3 \%$ for the $m c r A$ and $88.6 \%$ for bacterial $r r s$.

Gel images were acquired using an optical density calibrated scanner (Epson Scanner, Epson, France) at a spatial resolution of 600 d.p.i. and each band was considered an operational taxonomical unit. Images were analysed with GelCompar II version 4.0 (Applied Maths, Kortrijk, Belgium). Banding profiles were quantified within each profile by determining the total number of bands (S), the peak surface of each band (ni) and the sum of all the peak surfaces of all bands (N; Fromin et al., 2002). This was used to calculate the community biodiversity using three indices: (i) the Shannon index $(H)$ calculated as:

$$
H=-\Sigma\left(\frac{n i}{N}\right) \ln \left(\frac{n i}{N}\right)
$$

(ii) the dominance index $(c)$ calculated as:

$$
c=\Sigma\left(\frac{n i}{N}\right)^{2} ; \text { and }
$$

(iii) the evenness index (e) calculated as:

$$
e=\frac{H}{\ln S}
$$

according to Fromin et al. (2002) and Sadet et al. (2007).

DGGE profiles were normalised and compared using hierarchical clustering to join similar profiles into groups (Fromin et al., 2002). To this end, all images of DGGE gels were matched using the internal control sample and bands were quantified after local background subtraction. A tolerance in the band position of $1 \%$ was applied. The similarity among profiles was calculated with the Pearson product moment correlation coefficient and the clustering was done with the unweighted pair-group method using arithmetic averages (UPGMA).

\subsection{Microbial communities' quantification and gene expression}

Real time quantitative PCR was carried out using a StepOne ${ }^{\mathrm{TM}}$ system (Applied Biosystems, Courtabeuf, France). Assays were in triplicate using SYBR Premix Ex Taq ${ }^{\text {TM }}$ (Takara Bio Inc, Otsu, Japan) and were used $20 \mathrm{ng}$ of tNA or $20 \mu$ l of total cDNA. Negative controls without DNA template were run with every assay to assess overall specificity.

Primers used to quantify mcrA DNA or cDNA templates are in Table 2. Reaction volume was set to $25 \mu$ l supplemented with additional $1 \mathrm{mM} \mathrm{MgCl} 2$ and $0.3 \mu \mathrm{M}$ of each primer. The PCR parameters for mcrA sequence amplification were an initial denaturation step $\left(50^{\circ} \mathrm{C}\right.$ for $2 \mathrm{~min}$ and $95^{\circ} \mathrm{C}$ for $\left.1 \mathrm{~min}\right)$ and 40 cycles of amplification $\left(95^{\circ} \mathrm{C}\right.$ for $15 \mathrm{~s}, 60^{\circ} \mathrm{C}$ for $\left.1 \mathrm{~min}\right)$. Amplicon specificity was checked via dissociation curve analysis of PCR end products by increasing the temperature at a rate of $0.4^{\circ} \mathrm{C} / \mathrm{min}$ from 60 to $95^{\circ} \mathrm{C}$. Average amplification efficiency, slope and $R^{2}$ of qPCR assays targeting mcrA gene were of $96 \%,-3.43$ and 0.995 , respectively.

Bacterial rrs DNA quantification used primers targeting the V3 region of the bacterial rrs gene (Table 2). Assays were in a total volume of $20 \mu \mathrm{l}$ and the final concentration of rrs primers was $0.5 \mu \mathrm{M}$. The PCR parameters for rrs sequence amplification were an initial denaturation step at $95^{\circ} \mathrm{C}$ for $10 \mathrm{~min}$ and 40 cycles of amplification $\left(95^{\circ} \mathrm{C}\right.$ for $15 \mathrm{~s}, 60^{\circ} \mathrm{C}$ for $1 \mathrm{~min}$ ); the amplified product specificity was determined by dissociation curve analysis obtained by temperature increase from 60 to $95^{\circ} \mathrm{C}$ at the rate of $0.6^{\circ} \mathrm{C} / \mathrm{min}$. Average amplification efficiency, slope and $R^{2}$ of qPCR assays targeting rrs gene were of $89 \%,-3.64$ and 0.999 , respectively. 
Gene copies in rumen content samples were quantified and results expressed as gene copies/g DM of rumen content or total gene copies in whole rumen contents. Absolute quantification involved use of standard curves that had been prepared with PCR products corresponding to a partial sequence of mcrA gene of Methanobrevibacter ruminantium 1093 (DSM) and almost the entire sequence of rrs gene of Prevotella bryantii B14 (DSM 11371). Standard curves were created using triplicate fold dilutions series ranging from $2.5 \times 10^{2}$ to $2.5 \times 10^{8}$ copies for $m c r A$ gene and from $1 \times 10^{2}$ to $1 \times 10^{8}$ copies for bacterial rrs gene.

Expression of the functional mcrA gene was assessed using relative quantification by the threshold cycle (Ct) of the qPCR. Statistical analysis of gene expression was on the $2^{-\mathrm{Ct}}$ values as suggested by Schmittgen and Livak (2008).

\subsection{Statistical analysis}

To determine treatment effects of the diet on $\mathrm{CH}_{4}$ and VFA production, $\mathrm{pH}$, gene copy numbers and diversity indexes data from each animal were analysed using PROC MIXED of SAS (2003) with Tukey's adjustment. The model included diet as a fixed effect with bull (diet) as a random effect. Effects were declared significant at $\mathrm{P} \leq 0.05$ and trends were declared for $\mathrm{P}<0.10$.

\section{Results}

\subsection{Dry matter intake, $\mathrm{CH}_{4}$ output and fermentation parameters}

At the end of the fattening period, bulls fed the fibrous diet consumed more feed and had more rumen contents $(\mathrm{P}<0.01)$ than those fed SL (Table 3). Bulls fed F produced 21\% more $\mathrm{CH}_{4}(\mathrm{~g} / \mathrm{d})$ than those receiving SL $(\mathrm{P}<0.01)$. However, there was no difference between groups when emissions were calculated as $\mathrm{g} \mathrm{CH}_{4} / \mathrm{kg}$ DM intake or relative to gross energy intake.

At slaughter, total VFA molar concentration were not higher in bulls fed F compared to those fed SL. However the proportion of acetate was lower, whereas proportions of the isoacids (iso-valerate, iso-butyrate) were higher in bulls fed SL (Table 3). There was no difference between diets in propionate and butyrate molar proportions or in the acetate:propionate molar ratio. Ruminal pH was similar between the two groups of bulls.

\subsection{Microbial community structure}

Total nucleic acids (DNA and RNA) were extracted from whole rumen contents with similar yields between diets. The amount of RNA extracted when expressed as proportion of the tNA sample was equally similar across samples and diets (data not shown). After DNA digestion, RNA integrity was checked using an Agilent RNA 6000 Nano Kit. Electropherograms presented two major peaks corresponding to the $16 \mathrm{~S}$ and $23 \mathrm{~S}$ ribosomal RNA (rRNA). Mean RIN was 7.4 ( \pm 0.14 ) and mean rRNA 16S/rRNA 23S ratio was $0.97 \pm 0.22$.

Results of qPCR quantification of the Archaeal mcrA and bacterial rrs gene copies are summarized in Table 4. The mcrA gene concentration as well as total copy number in the rumen contents were similar between both groups of bulls. The concentration of bacterial rrs copies tended $(\mathrm{P}=0.09)$ to increase in bulls fed SL, but there was no difference in total rrs copies in rumen contents between diets. There was an increase of $>65 \%$ in protozoal numbers in bulls fed SL as compared to those

Table 3

Dry matter intake, $\mathrm{CH}_{4}$ output and rumen fermentation parameters in bulls $(n=20)$ fed a fibre or a starch-rich diet supplemented with lipids.

\begin{tabular}{|c|c|c|c|c|}
\hline & \multicolumn{2}{|l|}{ Diet $^{\mathrm{a}}$} & \multirow[t]{2}{*}{ SEM } & \multirow[t]{2}{*}{$\mathrm{P}$} \\
\hline & $\mathrm{F}$ & SL & & \\
\hline DM intake $(\mathrm{kg} / \mathrm{d})$ & 10.2 & 7.9 & 0.29 & $<0.01$ \\
\hline Total rumen contents $\left(\mathrm{kg} \mathrm{DM}^{\mathrm{b}}\right)$ & 6.4 & 4.7 & 0.33 & $<0.01$ \\
\hline $\mathrm{pH}$ & 6.7 & 6.9 & 0.05 & 0.12 \\
\hline \multicolumn{5}{|l|}{$\mathrm{CH}_{4}$ output } \\
\hline $\mathrm{CH}_{4}(\mathrm{~g} / \mathrm{d})$ & 357 & 282 & 16.21 & $<0.01$ \\
\hline $\mathrm{CH}_{4} / \mathrm{GE}$ intake $(\mathrm{g} / \mathrm{kg})^{\mathrm{c}}$ & 108 & 102 & 0.56 & 0.47 \\
\hline $\mathrm{CH}_{4} / \mathrm{DM}$ intake $(\mathrm{g} / \mathrm{kg})$ & 35 & 35.7 & 2.63 & 0.17 \\
\hline \multicolumn{5}{|l|}{ Fermentation parameters } \\
\hline Total VFA (mM) & 81.8 & 68.7 & 5.67 & 0.12 \\
\hline Acetate $(\mathrm{mmol} / \mathrm{mol})$ & 678 & 647 & 0.09 & 0.03 \\
\hline Propionate (mmol/mol) & 176 & 179 & 0.74 & 0.80 \\
\hline Butyrate $(\mathrm{mmol} / \mathrm{mol})$ & 98 & 107 & 0.62 & 0.32 \\
\hline Iso butyrate ( $\mathrm{mmol} / \mathrm{mol})$ & 13 & 19 & 0.10 & $<0.01$ \\
\hline Valerate $(\mathrm{mmol} / \mathrm{mol})$ & 10 & 14 & 0.09 & 0.02 \\
\hline Iso valerate $(\mathrm{mmol} / \mathrm{mol})$ & 20 & 30 & 0.37 & $<0.01$ \\
\hline Acetate/propionate & 3.9 & 3.7 & 0.19 & 0.36 \\
\hline
\end{tabular}

a Diet rich in fibre $(\mathrm{F})$ or rich in starch and supplemented with lipids (SL).

b DM, dry matter.

c GE, gross energy. 
Rumen microbial parameters in bulls $(n=20)$ fed a fibre or a starch-rich diet supplemented with lipids.

\begin{tabular}{|c|c|c|c|c|}
\hline & \multicolumn{2}{|l|}{ Diet $^{\mathrm{a}}$} & \multirow[t]{2}{*}{ SEM } & \multirow[t]{2}{*}{$\mathrm{P}$} \\
\hline & $\mathrm{F}$ & SL & & \\
\hline \multicolumn{5}{|l|}{ Microbial numbers } \\
\hline Bacterial rrs copy number/g DM ${ }^{\mathrm{b}}\left(\log _{10}\right)$ & 11.77 & 12.21 & 0.17 & 0.09 \\
\hline Total bacterial rrs copies $\left(\log _{10}\right)$ & 15.05 & 15.59 & 0.19 & 0.11 \\
\hline$m c r A$ copy number/g DM $\left(\log _{10}\right)$ & 9.02 & 9.07 & 0.16 & 0.83 \\
\hline Total mcrA copies $\left(\log _{10}\right)$ & 12.77 & 12.78 & 0.17 & 0.97 \\
\hline Protozoa cell/ml $\left(\times 10^{5}\right)$ & 4.28 & 13.2 & 1.42 & $<0.01$ \\
\hline \multicolumn{5}{|l|}{ Microbial diversity } \\
\hline rrs DNA band number & 45.8 & 49.8 & 1.8 & 0.13 \\
\hline rrs DNA Shannon diversity index & 1.54 & 1.58 & 0.02 & 0.11 \\
\hline rrs DNA evenness diversity index & 0.93 & 0.93 & 0.004 & 0.61 \\
\hline rrs DNA dominance diversity index & 0.035 & 0.031 & 0.002 & 0.14 \\
\hline$m c r A$ DNA band number & 19.6 & 14.5 & 0.9 & $<0.01$ \\
\hline mcrA DNA Shannon diversity index & 1.17 & 1.03 & 0.03 & $<0.01$ \\
\hline mcrA DNA evenness diversity index & 0.91 & 0.9 & 0.008 & 0.55 \\
\hline mcrA DNA dominance diversity index & 0.08 & 0.10 & 0.006 & $<0.01$ \\
\hline \multicolumn{5}{|l|}{ Gene expression } \\
\hline mcrA cDNA band number & 12.78 & 8 & 0.8 & $<0.01$ \\
\hline mcrA cDNA Shannon diversity index & 0.95 & 0.79 & 0.04 & $<0.01$ \\
\hline mcrA cDNA evenness diversity index & 0.86 & 0.88 & 0.02 & 0.39 \\
\hline mcrA cDNA dominance diversity index & 0.14 & 0.19 & 0.02 & $<0.05$ \\
\hline $\operatorname{mcrA} 2^{-\mathrm{Ct}}\left(\times 10^{-7}\right)$ & 1.72 & 0.867 & 0.187 & $<0.01$ \\
\hline
\end{tabular}

a Diet rich in fibre $(\mathrm{F})$ or rich in starch and supplemented with lipids (SL).

b DM, dry matter.

fed $\mathrm{F}$ (Table 4). Small Entodiniomorphs $(<100 \mu \mathrm{m})$ were predominant and tended $(\mathrm{P}=0.09)$ to be more abundant in bulls fed SL as compared to those fed $\mathrm{F}$ (983 versus 970 cells/1000 cells). Dasytricha were more abundant $(\mathrm{P}=0.05)$ in $\mathrm{F}$, but they represented just 30 cells per 1000 protozoal cells and there was no difference in large Entodiniomorphs and Isotricha sp. that represented on average 4.4 and 16.8 cells per 1000 protozoa, respectively.

Diversity indices were calculated from the mcrA and rrs DNA PCR-DGGE profiles (Table 4). The mcrA profiles in both DNA and cDNA samples had higher number of bands and Shannon diversity index $(\mathrm{P}<0.01)$ and lower dominance index in bulls fed $\mathrm{F}$ than in those fed SL, but the evenness index was similar between diets. There was no difference between diets neither in the number of bands nor in the values of the diversity indexes for the rrs DNA PCR-DGGE profiles.

Cluster analysis of $m c r A$ DNA PCR-DGGE profiles revealed differences in the rumen methanogenic community between bulls fed F and SL (Fig. 1). Most SL samples grouped together and formed a well defined cluster with similarity of $88.6 \%$ among samples. The band patterns for bulls fed F, although well separated from those receiving SL, did not generate a distinct cluster. The similarity between samples was 74.9\%. Concerning PCR-DGGE profiles for mcrA cDNA sequences (Fig. 2), samples from the 20 bulls had a high similarity without an obvious distinction in clusters between diets. Cluster analysis of the rrs DNA sequences did not show any difference in the bacterial community structure due to diet (data not shown). The mcrA cDNA amplicons were generated during qPCR from all samples. The mcrA $2^{-\mathrm{Ct}}$ values were lower in bulls fed SL than in bulls fed F (Table 4).

\section{Discussion}

DM intake, $\mathrm{CH}_{4}$ production and fermentation patterns are consistent with those obtained over the fattening period for the 50 bulls used in the companion paper (Eugène et al., in this issue). Net $\mathrm{CH}_{4}$ emissions $\left(\mathrm{CH}_{4} \mathrm{~g} / \mathrm{d}\right)$ were reduced by $21 \%$ in bulls fed SL compared to those fed F. Higher DM intake by bulls fed F resulted in a higher total weight of rumen contents compared to bulls fed SL. As a consequence of the higher DM intake with $\mathrm{F}$, there was no difference in $\mathrm{CH}_{4}$ emissions between diets when expressed as $\mathrm{g} \mathrm{CH}_{4} / \mathrm{kg}$ DM intake. These results may be due to the higher starch and lipid content of the SL diet as compared to diet F. However the lipids supplemented by extruded linseed accounted for only $20 \mathrm{~g} / \mathrm{kg}$ of DM in the SL diet, and previous studies showed that diets rich in starch reduced $\mathrm{CH}_{4}$ production in feedlot cattle (Beauchemin and McGinn, 2005; Doreau et al., 2011). Moreover, the supply of lipids from linseed decreased the amount of $\mathrm{CH}_{4}$ emitted by dairy cows (Martin et al., 2008), although Woodward et al. (2006) found no effect of lipid supplementation on methanogenesis in a long term study with dairy cows, suggesting that effects of lipids on $\mathrm{CH}_{4}$ emissions are transitory. In their review, Martin et al. (2010) reported a decrease in $\mathrm{CH}_{4}$ production of $4.8 \%$ with each supplement of $10 \mathrm{~g}$ linseed lipids $/ \mathrm{kg}$ DM added to the ration, and suggested that effect of lipids on methanogenesis may depend on diet.

There were no large differences in rumen fermentation parameters between diets. As a result of the high starch content of the SL diet, there was a decrease in the proportion of acetate in rumen fluid. However, the acetate:propionate ratio remained constant in the two groups. Lack of differences in the acetate propionate ratio precludes a stoichiometric shift in $\mathrm{H}_{2}$ utilisation. In addition, rumen $\mathrm{pH}$ which is also highly positively correlated to $\mathrm{CH}_{4}$ production (Lana et al., 1998), was not 


\section{Pearson Correlation marADNA} $[0.0 \%-100.0 \%]$
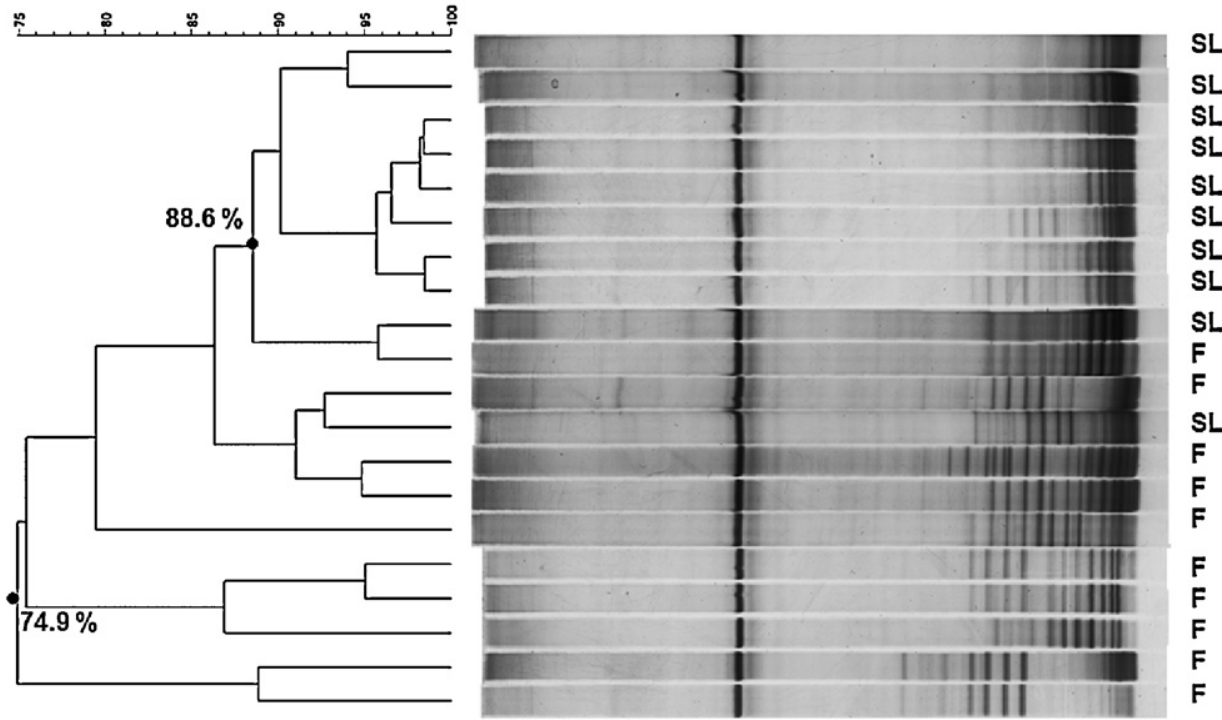

Fig. 1. PCR-DGGE profiles of present rumen methanogens (mcrA DNA) in bulls $(n=20)$ fed a fibre (F) or a starch-rich diet supplemented with lipids (SL). The similarity among profiles was calculated with the Pearson product-moment correlation coefficient and the clustering was done with the unweighted pair-group method using arithmetic averages (UPGMA).

\section{Pearson Correlation $[0.0 \%-100.0 \%] \quad$ mcrAcDNA}

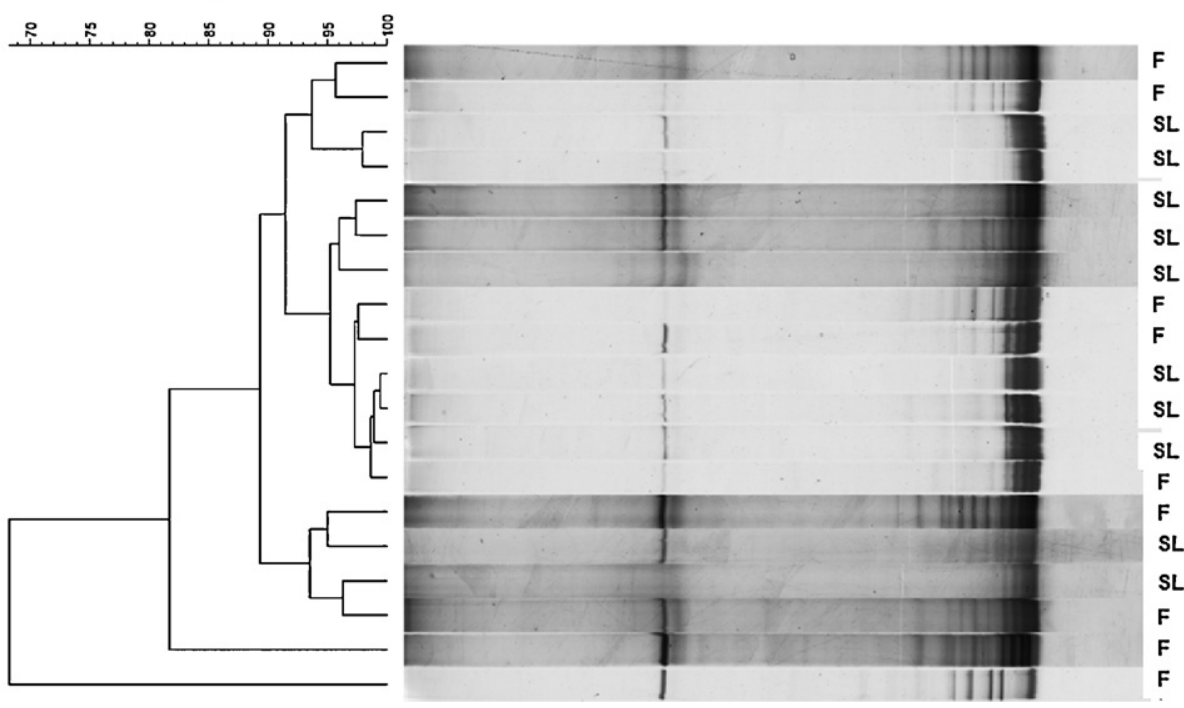

Fig. 2. PCR-DGGE profiles of metabolically active rumen methanogens (mcrA cDNA) in bulls $(n=20)$ fed a fibre (F) or a starch-rich diet supplemented with lipids (SL). The similarity among profiles was calculated with the Pearson product-moment correlation coefficient and the clustering was done with the unweighted pair-group method using arithmetic averages (UPGMA).

affected by the starch rich diet (Table 3 and Eugène et al., in this issue). The absence of ruminal fermentation changes partly explains the lack of differences in $\mathrm{CH}_{4}$ emission/ $\mathrm{kg}$ DM intake. Martin et al. (2010) suggested that a low acetate:propionate ratio and depressed $\mathrm{CH}_{4}$ production may not always be linked in high concentrate feeding in ruminants.

Lipids are known to have toxic effects on rumen microbes. Linolenic acid, abundant in linseed oil, has inhibitory activity against a range of common rumen bacteria in pure culture with cellulolytic bacteria being particularly sensitive (Maia et al., 2007). As discussed above, the concentration of linseed lipids in the rumen of SL fed bulls was low and unlikely to affect rumen microbes as evaluated by the absence of quantitative (qPCR) and qualitative (DGGE) changes in bacteria. However, the tools we used targeted total bacteria and so gave only a global overview of this microbial community. In contrast protozoa 
increased in numbers, likely due to the higher proportion of starch in the SL diet (Mackie et al., 1978). Additionally, as mentioned above for bacteria, the concentration of linolenic acid in the SL diet was probably not toxic to protozoa. The increase in isobutyric and isovaleric acids, which results from deamination of valine and leucine respectively, can also be associated with higher protein degradation by protozoa (Eugène et al., 2004). This is consistent with the higher protozoal concentrations in the rumen of the bulls fed diet SL.

That the total number and concentration of mcrA copy numbers in the rumen contents of bulls was not influenced by diet is comparable to results reported with high and low RFI steers fed high and low energy diets (Zhou et al., 2010), although in the latter study there were no measures of $\mathrm{CH}_{4}$ production. Lipid supplementation of diets depressed $\mathrm{CH}_{4}$ production in sheep by $14 \%$ without affecting numbers of methanogen numbers (Machmüller et al., 2003), suggesting that the number of rumen methanogens may not be a key factor affecting $\mathrm{CH}_{4}$ production in all situations.

Intake of fibrous concentrate enhanced development of a more diverse methanogenic community as shown by the higher number of bands and higher Shannon index of PCR-DGGE profiles from F compared to SL. Also, individual variability among bulls fed diet SL was less marked, as they grouped together in a well defined distinct cluster. As the SL diet was rich in starch and contained oil, it may have had a specific selection pressure on the methanogenic community. However, PCR-DGGE analysis of mcrA cDNA sequences did not reveal an impact of diet on metabolically active community members. Changing from a low to a high concentrate diet has been reported to have an impact on the structure of the methanogenic community (Zhou et al., 2010), and these authors suggested that diet composition may specifically select methanogens that differ in their methanogenic pathway and differences at the strain or genotype level may play an important role in $\mathrm{CH}_{4}$ production (Zhou et al., 2010).

Expression of the functional mcrA gene suggested that methanogens in bulls fed SL were less metabolically active than in bulls fed F. Accordingly, $\mathrm{CH}_{4}$ production by these bulls $(\mathrm{g} / \mathrm{d})$ was lower than that from bulls fed $\mathrm{F}$. A decrease in $\mathrm{CH}_{4}$ production associated with lower methanogenic activity has been described in sheep fed coconut oil (Machmüller et al., 2003). A decrease in $\mathrm{CH}_{4}$ emissions may be due to a lower $\mathrm{CH}_{4}$ production rate per single methanogenic cell and could depend on availability of $\mathrm{H}_{2}$ as a substrate.

Dihydrogen is a major end product of protozoa metabolism, suggesting that the higher $\mathrm{CH}_{4}$ production/kg DM intake may be due to a higher production of $\mathrm{H}_{2} / \mathrm{kg}$ DM intake in bulls fed SL. This is consistent with the higher total tract digestibility in faunated compared to defaunated ruminants (Eugène et al., 2004). The extent of feed digestion in bulls fed SL, compared to those fed F, may have been enhanced by the higher protozoal population and thereby provide abundant $\mathrm{H}_{2}$ for methanogenesis.

\section{Conclusions}

High starch diets and/or lipid supplementation are feeding strategies known to mitigate $\mathrm{CH}_{4}$ emissions by ruminants without affecting their production. Differences in $\mathrm{CH}_{4}$ production under two diet conditions in our study could be attributed to changes in rumen microbiota, particularly to methanogen activity, whereas other changes, such as the increase in protozoal numbers in the starch rich diet, may have diminished the $\mathrm{CH}_{4}$ abatement potential of this diet. As to bacteria, further studies are needed to evaluate effects of diet on this microbial community. To better understand the effect of dietary, and other, $\mathrm{CH}_{4}$ mitigations in ruminants, it seems essential to use a holistic approach in studying the rumen ecosystem. Interactions involving $\mathrm{H}_{2}$ producers and methanogens and other $\mathrm{H}_{2}$ users in the rumen should be better explored as they could open new targets for modification of the rumen microbiota for mitigation purposes.

\section{Conflict of interest}

None.

\section{Acknowledgements}

This experiment has been granted by the regional council of the French "Centre" region, by McKey Food Services (Fleury les Aubrais, France) and by Valorex (Combourtillé, France). The authors greatly thank the technicians of Experimental Unit Bourges and Experimental Unit Theix for taking care of the animals and the personal of the Experimental Abattoir of INRA Theix for help with sampling. M. Popova is the recipient of INRA - Région Auvergne scholarship.

\section{References}

Baldwin, R.L., Allison, M.J., 1983. Rumen metabolism. J. Anim. Sci. 57, 461-477.

Beauchemin, K.A., McGinn, S.M., 2005. Methane emissions from feedlot cattle fed barley or corn diets. J. Anim. Sci. 83, $653-661$.

Beauchemin, K.A., Kreuzer, M., O’Mara, F., McAllister, T.A., 2008. Nutritional management for enteric methane abatement: a review. Aust. J. Exp. Agric. 48, 21-27.

Denman, S.E., Tomkins, N.W., McSweeney, C.S., 2007. Quantitation and diversity analysis of ruminal methanogenic populations in response to the antimethanogenic compound bromochloromethane. FEMS Microbiol. Ecol. 62, 313-322.

Doreau, M., van der Werf, H.M.G., Micol, D., Dubroeucq, H., Agabriel, J., Rochette, Y., Martin, C., 2011. Enteric methane production and greenhouse gases balance of diets differing in concentrate in the fattening phase of a beef production system. J. Anim. Sci., doi:10.2527/jas.2010.3140. 
Edwards, J.E., Huws, S.A., Kim, E.J., Kingston-Smith, A.H., 2007. Characterization of the dynamics of initial bacterial colonization of nonconserved forage in the bovine rumen. FEMS Microbiol. Ecol. 62, 323-335.

Eugene, M., Masse, D., Chiquette, J., Benchaar, C., 2008. Meta-analysis on the effects of lipid supplementation on methane production in lactating dairy cows. Can. J. Anim. Sci. 88, 331-334.

Eugène, M., Archimède, H., Sauvant, D., 2004. Quantitative meta-analysis on the effects of defaunation of the rumen on growth, intake and digestion in ruminants. Livest. Prod. Sci. 85, 81-97.

Eugène, M., Martin, C., Mialon, M.M., Krauss, D., Renand, G., Doreau, M. Dietary linseed and starch supplementation decreases methane production of fattening bulls. Anim. Feed Sci. Technol., in this issue.

Fromin, N., Hamelin, J., Tarnawski, S., Roesti, D., Jourdain-Miserez, K., Forestier, N., Teyssier-Cuvelle, S., Gillet, F., Aragno, M., Rossi, P., 2002. Statistical analysis of denaturing gel electrophoresis (DGE) fingerprinting patterns. Environ. Microbiol. 4, 634-643.

Lana, R.P., Russell, J.B., Van Amburgh, M.E., 1998. The role of pH in regulating ruminal methane and ammonia production. J. Anim. Sci. 76, $2190-2196$.

Luton, P.E., Wayne, J.M., Sharp, R.J., Riley, P.W., 2002. The mcrA gene as an alternative to 16S rRNA in the phylogenetic analysis of methanogen populations in landfill. Microbiology 148, 3521-3530.

Machmüller, A., Soliva Carla, R., Michael, K., 2003. Effect of coconut oil and defaunation treatment on methanogenesis in sheep. Reprod. Nutr. Dev. 43, 41-55.

Mackie, R.I., Gilchrist, F.M.C., Robberts, A.M., Hannah, P.E., Schwartz, H.M., 1978. Microbiological and chemical changes in the rumen during the stepwise adaptation of sheep to high concentrate diets. J. Agric. Sci. 90, 241-254.

Maia, M.R.G., Chaudhary, L.C., Figueres, L., Wallace, R.J., 2007. Metabolism of polyunsaturated fatty acids and their toxicity to the microflora of the rumen. Antonie Van Leeuwenhoek 91, 303-314.

Martin, C., Rouel, J., Jouany, J.P., Doreau, M., Chilliard, Y., 2008. Methane output and diet digestibility in response to feeding dairy cows crude linseed, extruded linseed, or linseed oil. J. Anim Sci., 2007-0774.

Martin, C., Morgavi, D.P., Doreau, M., 2010. Methane mitigation in ruminants: from microbe to the farm scale. Animal 4, $351-365$.

Morgavi, D.P., Boudra, H., Jouany, J.P., Graviou, D., 2003. Prevention of patulin toxicity on rumen microbial fermentation by SH-containing reducing agents. J. Agric. Food. Chem. 51, 6906-6910.

Muyzer, G., de Waal, E.C., Uitterlinden, A.G., 1993. Profiling of complex microbial populations by denaturing gradient gel electrophoresis analysis of polymerase chain reaction-amplified genes coding for 16S rRNA. Appl. Environ. Microbiol. 59, 695-700.

Newbold, C.J., Lassalas, B., Jouany, J.P., 1995. The importance of methanogens associated with ciliate protozoa in ruminal methane production in vitro. Lett. Appl. Microbiol. 21, 230-234.

Popova, M., Martin, C., Rochette, Y., Graviou, D., Morgavi, D.P., 2010a. Methane emissions and rumen methanogens in sheep harbouring or not protozoa. In: Proc. of the 7th Joint Symposium RRI-INRA “Gut Microbiology: new insights into gut microbial ecosystems” , Aberdeen, UK.

Popova, M., Martin, C., Morgavi, D.P., 2010b. Improved protocol for hight-quality coextraction of DNA and RNA from rumen digesta. Folia Microbiol. 55, 368-372.

Ranilla, M.J., Jouany, J.P., Morgavi, D.P., 2007. Methane production and substrate degradation by rumen microbial communities containing single protozoal species in vitro. Lett. Appl. Microbiol. 45, 675-680.

Rouviere, P.E., Wolfe, R.S., 1988. Novel biochemistry of methanogenesis. J. Biol. Chem. 263, 7913-7916.

Sadet, S., Martin, C., Meunier, B., Morgavi, D.P., 2007. PCR-DGGE analysis reveals a distinct diversity in the bacterial population attached to the rumen epithelium. Animal 1, 939-944.

Statistical Analysis System, 2003. SAS PC Windows Version 9.1.2. SAS Institute Inc., Cary, NC, USA.

Schmittgen, T.D., Livak, K.J., 2008. Analyzing real-time PCR data by the comparative Ct method. Nat. Protoc. 3, 1101-1108.

Schroeder, A., Mueller, O., Stocker, S., Salowsky, R., Leiber, M., Gassmann, M., Lightfoot, S., Menzel, W., Granzow, M., Ragg, T., 2006. The RIN: an RNA integrity number for assigning integrity values to RNA measurements. BMC Mol. Biol. 7, 3.

Woodward, S.L., Waghorn, G.C., Thomson, N.A., 2006. Supplementing dairy cows with oils to improve performances and reduce methane - does it work? Proc N. Z. Soc. Anim. Prod. 66, 176-181.

Zhou, M., Hernandez-Sanabria, E., Guan, L.L., 2009. Assessment of the microbial ecology of ruminal methanogens in cattle with different feed efficiencies. Appl. Environ. Microbiol. 75, 6524-6533.

Zhou, M., Hernandez-Sanabria, E., Guan, L.L., 2010. Characterization of variation in rumen methanogenic communities under different dietary and host feed efficiency conditions, as determined by PCR-Denaturing Gradient Gel Electrophoresis analysis. Appl. Environ. Microbiol. 76, 3776-3786. 